\title{
Dongia mobilis gen. nov., sp. nov., a new member of the family Rhodospirillaceae isolated from a sequencing batch reactor for treatment of malachite green effluent
}

Correspondence

Zhi-Pei Liu

liuzhp@sun.im.ac.cn

\author{
Ying Liu, ${ }^{1}$ Jing-Hua Jin, ${ }^{2}$ Ying-Hao Liu, ${ }^{1}$ Yu-Guang Zhou ${ }^{1}$ \\ and Zhi-Pei Liu ${ }^{1}$ \\ ${ }^{1}$ State Key Laboratory of Microbial Resources, Institute of Microbiology, Chinese Academy of \\ Sciences, Beijing 100101, PR China \\ ${ }^{2}$ Environmental Protection Research Institute of Light Industry, Beijing 100089, PR China
}

The family Rhodospirillaceae, of subgroup 1 of the class Alphaproteobacteria, comprises 22 genera at the time of writing (http://www.bacterio.cict.fr/classifgenerafamilies. html\#Rhodospirillaceae). Members of several novel genera of this family have been isolated recently from various environments, such as Caenispirillum bisanense from sludge of a dye works (Yoon et al., 2007), Fodinicurvata fenggangensis and $F$. sediminis from a salt mine (Wang et al., 2009), Marispirillum indicum from a deep-sea environment (Lai et al., 2009a), Nisaea denitrificans and N. nitritireducens from surface seawater (Urios et al., 2008), Oceanibaculum indicum from deep seawater (Lai et al., 2009b), Pelagibius litoralis from seawater (Choi et al., 2009), Thalassobaculum litoreum from coastal seawater (Zhang et al., 2008) and Telmatospirillum siberiense from a mesotrophic fen (Sizova et al., 2007). The wide distribution

The GenBank/EMBL/DDBJ accession number for the $16 \mathrm{~S}$ rRNA gene sequence of strain $L^{2} 22^{\top}$ is FJ455532.

A transmission electron micrograph of a cell of strain $L M 22^{\top}$ and fatty acid compositions of members of the family Rhodospirillaceae are available as supplementary material with the online version of this paper. and metabolic diversity (such as heterotrophism or phototrophism) of the family Rhodospirillaceae suggest that its members may have an important role in such aquatic and marine environments.

Malachite green is an $\mathrm{N}$-methylated diamino-triphenylmethane dye that can be toxic to human cells and promotes liver tumour formation in rodents (Alderman, 1985; Srivastava et al., 2004). In an investigation of the culturable microbial diversity in the activated sludge of a sequencing batch reactor for the treatment of malachite green effluent, many bacterial strains were isolated and characterized taxonomically. In this study, we report the isolation and characterization of a novel strain, $\mathrm{LM} 22^{\mathrm{T}}$, of the family Rhodospirillaceae.

A sludge sample was suspended in normal saline by vigorous vortexing and $0.1 \mathrm{ml}$ suspension was spread onto 1/10-diluted trypticase soy agar (TSA; Difco) and incubated at $30{ }^{\circ} \mathrm{C}$ for 1 week. Single colonies were picked and a pure culture of strain $\mathrm{LM} 22^{\mathrm{T}}$ was obtained after subcultivation on YP agar $\left[1^{-1}: 3.0 \mathrm{~g}\right.$ tryptone (Difco), $3.0 \mathrm{~g}$ yeast extract (Difco), $0.5 \mathrm{~g} \quad \mathrm{MgSO}_{4} \cdot 7 \mathrm{H}_{2} \mathrm{O}, 0.3 \mathrm{~g}$ 
$\mathrm{NaCl}, 15 \mathrm{~g}$ agar; $\mathrm{pH}$ 7.0]. Strain $\mathrm{LM} 22^{\mathrm{T}}$ was maintained on YP agar and stored in $15 \%(\mathrm{w} / \mathrm{v})$ glycerol at $-80{ }^{\circ} \mathrm{C}$.

Growth on other bacteriological media was tested using R2A agar [laboratory prepared, containing (per litre distilled water): $0.5 \mathrm{~g}$ tryptone (Difco), $0.5 \mathrm{~g}$ yeast extract (Difco), $0.5 \mathrm{~g}$ Casamino acids, $0.5 \mathrm{~g}$ glucose, $0.5 \mathrm{~g}$ soluble starch, $0.3 \mathrm{~g}$ sodium pyruvate, $0.3 \mathrm{~g} \mathrm{~K}_{2} \mathrm{HPO}_{4}, 0.05 \mathrm{~g}$ $\mathrm{MgSO}_{4} \cdot 7 \mathrm{H}_{2} \mathrm{O}, 15 \mathrm{~g}$ agar; adjusted to $\mathrm{pH} 7.0-7.2$ using $1 \mathrm{M} \mathrm{NaOH}$ ], Luria-Bertani (LB) agar (Oxoid), nutrient agar (laboratory prepared) and TSA. Abundant growth was observed on R2A. No growth was seen on LB agar, NA or TSA. Gram-staining was performed as described by Gerhardt et al. (1994). Cell morphology was observed by phase-contrast microscopy and transmission electron microscopy (H600; Hitachi). Motility was determined according to Dong \& Cai (2001), by checking the turbidity throughout a tube containing semisolid YP agar. Flagellation was confirmed by transmission electron microscopy. Cells of strain $\mathrm{LM} 22^{\mathrm{T}}$ were Gram-negative, slightly curved to straight rods, $0.3-0.5 \mu \mathrm{m}$ wide and $0.6-1.0 \mu \mathrm{m}$ long, and were motile by a single polar flagellum (Supplementary Fig. S1, available in IJSEM Online).

Conditions for growth were tested in YP broth. Growth was tested at $\mathrm{pH} 5.0-11.0$ (at intervals of $0.5 \mathrm{pH}$ units), at $15-45{ }^{\circ} \mathrm{C}$ (at intervals of $5{ }^{\circ} \mathrm{C}$ ) and with $0-2.5 \%(\mathrm{w} / \mathrm{v})$ $\mathrm{NaCl}$ (at intervals of $0.5 \% \mathrm{NaCl}$ ). Growth occurred at 20 $40{ }^{\circ} \mathrm{C}$ (optimum $30-35{ }^{\circ} \mathrm{C}$ ) and $\mathrm{pH}$ 6.0-10.0 (optimum $\mathrm{pH}$ 7.0-7.5). Strain $\mathrm{LM}_{2} 2^{\mathrm{T}}$ did not require $\mathrm{NaCl}$ for growth and tolerated up to $2.0 \% \mathrm{NaCl}$ (optimum $0.5 \%$ ).

Catalase and oxidase activities, $\mathrm{H}_{2} \mathrm{~S}$ production, hydrolysis of casein, starch and Tweens 20, 40, 60 and 80 were tested using standard methods (Cowan \& Steel, 1965; Bruns et al., 2001). Assimilation of carbon sources was determined at $30{ }^{\circ} \mathrm{C}$ after 1, 3, 7 and 14 days according to Dong \& Cai (2001) using the standard mineral base of Stanier et al. (1966) and, after autoclaving, adding filter-sterilized compounds to a concentration of $0.5 \%(\mathrm{w} / \mathrm{v})$. Other physiological tests were performed using the API ZYM and API 20NE systems (bioMérieux), according to the manufacturer's instructions. Susceptibility to antibiotics was determined on YP agar using filter-paper discs (Beijing Pharmaceutical Company). The physiological and biochemical characteristics of strain $\mathrm{LM} 22^{\mathrm{T}}$ are given in the genus and species descriptions and the characteristics that differentiated the isolate from phylogenetically related genera are listed in Table 1.

Phototrophic growth was determined in an Oxoid AnaeroGen system using the medium of Pfennig \& Trüper (1974) according to Imhoff \& Caumette (2004). Strain $\mathrm{LM} 22^{\mathrm{T}}$ was unable to grow photoautotrophically with $0.1 \%$ $(\mathrm{w} / \mathrm{v})$ thiosulfate or $0.1 \%(\mathrm{w} / \mathrm{v}) \mathrm{NaHCO}_{3}$ or photoheterotrophically with $0.1 \%(\mathrm{w} / \mathrm{v})$ methanol or $0.3 \%(\mathrm{w} / \mathrm{v})$ yeast extract, tryptone, sodium acetate or sodium pyruvate.

The $16 \mathrm{~S}$ rRNA gene of strain LM $22^{\mathrm{T}}$ was amplified using two bacterial universal primers, 27F and 1492R (Lane,
1991), and sequenced as described previously (Zhang et al., 2003). An almost-complete 16S rRNA gene sequence $(1458 \mathrm{nt})$ was subjected to comparative analysis in GenBank using the BLAST program (Altschul et al., 1990). A multiple alignment with sequences from closely related members was created using the CLUSTAL_X program (Thompson et al., 1997). Ambiguous bases and gaps in the alignment were manually removed and a phylogenetic tree was constructed using the evolutionary distance matrix calculated using the neighbour-joining method in MEGA version 3.1 (Kumar et al., 2004). The $16 \mathrm{~S}$ rRNA gene sequence phylogenetic tree showed that strain $\mathrm{LM} 22^{\mathrm{T}}$ formed a deep lineage in the family Rhodospirillaceae with Inquilinus limosus AU0476 ${ }^{\mathrm{T}}$ (Fig. 1). Strain $\mathrm{LM} 22^{\mathrm{T}}$ exhibited highest 16S rRNA sequence similarity with $I$. limosus AU0476 ${ }^{\mathrm{T}}$ (90.4\%) and less than $90 \%$ similarity with other members of the family Rhodospirillaceae.

Isoprenoid quinones were extracted and analysed as described by Komagata \& Suzuki (1987). Strain LM $22^{\mathrm{T}}$ contained Q-10 as the sole respiratory quinone. For fatty acid methyl ester analysis, cell mass was obtained from YP agar after cultivation at $30{ }^{\circ} \mathrm{C}$ for 3 days and the fatty acids were extracted, methylated and analysed using the Sherlock Microbial Identification System (MIDI), according to the manufacturer's instructions. The fatty acid profile of strain $\mathrm{LM} 22^{\mathrm{T}}$ is summarized in the species description and is compared with members of the most phylogenetically closely related genera in Supplementary Table S1. The major fatty acid was $\mathrm{C}_{18: 1} \omega 7 c(32.9 \%)$, which is a common feature of members of the class Alphaproteobacteria (Labrenz et al., 2000). Strain $\mathrm{LM} 22^{\mathrm{T}}$ had a slightly smaller amount of $\mathrm{C}_{18: 1} \omega \mathrm{\omega} 7 \mathrm{c}$ than its closest phylogenetic neighbour, I. limosus AU0476 ${ }^{\mathrm{T}}$, and could be distinguished from I. limosus AU0476 ${ }^{\mathrm{T}}$ by having $\mathrm{C}_{19: 0}$ cyclo $\omega 8 \mathrm{c}$ (18.7\%), $\mathrm{C}_{16: 0}(12.1 \%)$ and $\mathrm{C}_{16: 0} 2-\mathrm{OH}(10.5 \%)$ as major fatty acids but $\mathrm{C}_{18: 1} 2-\mathrm{OH}(4.5 \%)$ as a minor fatty acid. Furthermore, strain $\mathrm{LM} 22^{\mathrm{T}}$ could be differentiated from members of other related genera by having larger proportions of $\mathrm{C}_{19: 0}$ cyclo $\omega 8 c, \mathrm{C}_{16: 0}$ 2-OH, 11-methyl $\mathrm{C}_{18: 1} \omega 7 c(5.1 \%)$ and $\mathrm{C}_{14: 0}(4.1 \%)$. The DNA G+C content was determined by the thermal denaturation method (Sly et al., 1986), using DNA from Escherichia coli $\mathrm{K}-12$ as a control. The DNA G $+\mathrm{C}$ content of strain LM $22^{\mathrm{T}}$ was $65.6 \mathrm{~mol} \%$.

Although strain $\mathrm{LM} 22^{\mathrm{T}}$ was shown to be most closely related phylogenetically to I. limosus AU0476 ${ }^{\mathrm{T}}$, it differed from I. limosus AU0476 ${ }^{\mathrm{T}}$ in several characteristics, such as catalase activity, nutrient requirement for growth and DNA $\mathrm{G}+\mathrm{C}$ content. Furthermore, the $16 \mathrm{~S}$ rRNA gene sequence similarity between strain $\mathrm{LM} 22^{\mathrm{T}}$ and I. limosus AU0476 ${ }^{\mathrm{T}}$ was too low $(90.4 \%)$ to allow its assignment to the genus Inquilinus. Strain $\mathrm{LM} 22^{\mathrm{T}}$ showed less than $90 \% 16 \mathrm{~S}$ rRNA gene sequence similarity to other members of the family Rhodospirillaceae, and several important phenotypic and chemotaxonomic properties also differentiated the isolate from other taxa. Therefore, on the basis of phenotypic, chemotaxonomic and phylogenetic data, strain $\mathrm{LM} 22^{\mathrm{T}}$ is 
Table 1. Characteristics that distinguish strain $L M 22^{\top}$ from phylogenetically related genera in the family Rhodospirillaceae

Taxa: 1, Dongia mobilis gen. nov., sp. nov. (strain LM22 ${ }^{\mathrm{T}}$ ); 2, Inquilinus (data from Coenye et al., 2002); 3, Azospirillum (Tarrand et al., 1978; Reinhold et al., 1987; Khammas et al., 1989; Sly \& Stackebrandt, 1999; Eckert et al., 2001; Xie \& Yokota, 2005; Peng et al., 2006; Mehnaz et al., 2007a, b; Young et al., 2008; Lin et al., 2009); 4, Nisaea (Urios et al., 2008); 5, Oceanibaculum (Lai et al., 2009b; Dong et al., 2010); 6, Rhodocista (Favinger et al., 1989; Kawasaki et al., 1992; Imhoff et al., 1998; Zhang et al., 2003); 7, Skermanella (Sly \& Stackebrandt, 1999); 8, Thalassobaculum (Zhang et al., 2008; Urios et al., 2010). +, Positive; w, weakly positive; v, variable; -, negative; ND, no data available.

\begin{tabular}{|c|c|c|c|c|c|c|c|c|}
\hline Characteristic & 1 & 2 & 3 & 4 & 5 & 6 & 7 & 8 \\
\hline Isolation source(s) & $\begin{array}{l}\text { Sludge from } \\
\text { bioreactor }\end{array}$ & Cystic fibrosis patients & $\begin{array}{l}\text { Soil, roots, } \\
\text { fresh water }\end{array}$ & Seawater & $\begin{array}{l}\text { Deep seawater, } \\
\text { marine sediment }\end{array}$ & $\begin{array}{r}\text { Fresh water, } \\
\text { wastewater }\end{array}$ & Lake water & Coastal seawater \\
\hline Colony colour(s) & White & Not pigmented & Pink, white & Cream & Grey & Red, pink & Apricot & Cream-yellow \\
\hline Cell shape & $\begin{array}{l}\text { Curved } \\
\text { rods }\end{array}$ & Rods & Plump vibrioids or rods & Rods & Rods & Vibrioids, spirals & Rods & Pleomorphic rods \\
\hline Oxidase & - & $\mathrm{v}$ & + & - & + & $\mathrm{ND}$ & + & + \\
\hline Catalase & - & + & + & + & $\mathrm{V}$ & $\mathrm{ND}$ & + & + \\
\hline Gelatinase & - & $\mathrm{v}$ & $\mathrm{V}$ & ND & - & $\mathrm{ND}$ & - & + \\
\hline \multicolumn{9}{|l|}{ Growth temperature $\left({ }^{\circ} \mathrm{C}\right)$} \\
\hline Range & $20-40$ & $25-42$ & $4-41$ & $15-44$ & $10-45$ & $25-47$ & $10-37$ & $10-37$ \\
\hline Optimum & $30-35$ & $\mathrm{ND}$ & $20-41$ & 30 & $25-37$ & $31-45$ & 28 & $30-35$ \\
\hline \multicolumn{9}{|l|}{$\mathrm{pH}$ for growth } \\
\hline Range & $6-10$ & $\mathrm{ND}$ & $5-8.5$ & $5-9$ & $6-11$ & $5.7-8$ & $\mathrm{ND}$ & $5-10$ \\
\hline Optimum & $7-7.5$ & ND & $5-7.2$ & 6 & $7-9$ & $6.8-7$ & $\mathrm{ND}$ & 8 \\
\hline $\begin{array}{l}\text { Maximum } \mathrm{NaCl} \text { concentration } \\
(\%, \mathrm{w} / \mathrm{v})\end{array}$ & $\leqslant 2$ & $<6$ & $<5$ & $\leqslant 6$ & $\leqslant 9$ & $\mathrm{ND}$ & $<5$ & $\leqslant 10$ \\
\hline Bacteriochlorophyll $a$ & - & $\mathrm{ND}$ & - & $\mathrm{ND}$ & - & + & - & - \\
\hline Major quinone & Q-10 & $\mathrm{ND}$ & Q-10 & Q-10 & $\mathrm{ND}$ & Q-9 & Q-10 & Q-10 \\
\hline \multicolumn{9}{|l|}{ Utilization of: } \\
\hline L-Arabinose & $\mathrm{w}$ & - & $\mathrm{v}$ & - & - & $\mathrm{ND}$ & + & $\mathrm{V}$ \\
\hline D-Glucose & $\mathrm{W}$ & - & $\mathrm{v}$ & + & - & - & + & $\mathrm{v}$ \\
\hline L-Rhamnose & - & - & $\mathrm{v}$ & - & $\mathrm{v}$ & ND & + & - \\
\hline Sucrose & $\mathrm{w}$ & - & $\mathrm{v}$ & - & - & - & $\mathrm{ND}$ & $\mathrm{V}$ \\
\hline Citrate & - & - & $\mathrm{v}$ & - & - & - & + & - \\
\hline Inositol & - & - & $\mathrm{V}$ & - & - & ND & - & - \\
\hline DNA $G+C$ content $(\mathrm{mol} \%)$ & 65.6 & 70.3 & $64-71$ & 60 & $64.8-67.7$ & $68.3-69.9$ & 67.2 & $65-68$ \\
\hline
\end{tabular}




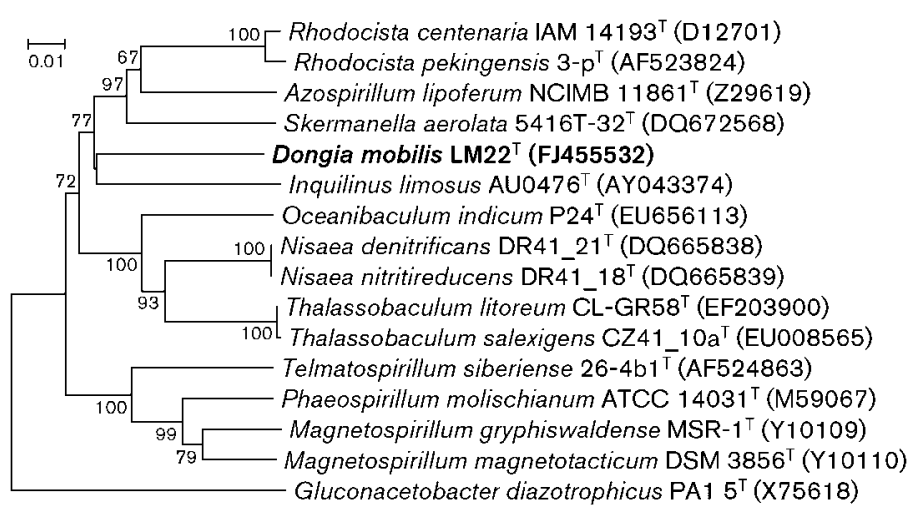

Fig. 1. Neighbour-joining tree based on $16 \mathrm{~S}$ rRNA gene sequences showing the phylogenetic position of strain $\mathrm{LM}_{2}{ }^{\top}$ and representatives of some other related taxa. Bootstrap values $(>70 \%)$ based on 1000 replications are shown at branch nodes. The sequence of Gluconacetobacter diazotrophicus PA1 $5^{\top}$ was used as an outgroup. Bar, 0.01 substitutions per nucleotide position. considered to represent a novel genus and species of the family Rhodospirillaceae, for which we propose the name Dongia mobilis gen. nov., sp. nov.

\section{Description of Dongia gen. nov.}

Dongia (Don'gi.a. N.L. fem. n. Dongia after Professor XiuZhu Dong, a bacteriologist and bacterial taxonomist in China).

Cells are Gram-negative, non-spore-forming, motile, slightly curved to straight rods. Strictly aerobic and heterotrophic. Never phototrophic. Internal membrane system and bacteriochlorophyll $a$ are absent. Negative for oxidase and catalase. Reduces nitrate to nitrite. Major fatty acids are $\mathrm{C}_{18: 1} \omega 7 c, \mathrm{C}_{19: 0}$ cyclo $\omega 8 c, \mathrm{C}_{16: 0}$ and $\mathrm{C}_{16: 0} 2-\mathrm{OH}$. The major ubiquinone is $\mathrm{Q}-10$. The DNA G $+\mathrm{C}$ content of the type strain of the type species is $65.6 \mathrm{~mol} \%$. The type species is Dongia mobilis.

\section{Description of Dongia mobilis sp. nov.}

Dongia mobilis (mo'bi.lis. L. fem. adj. mobilis motile, pertaining to the motility of the type strain).

Exhibits the following properties in addition to those given in the genus description. Cells are $0.3-0.5 \mu \mathrm{m}$ wide and $0.6-$ $1.0 \mu \mathrm{m}$ long. Colonies on YP agar are white, transparent, smooth, circular, convex and $0.5-1 \mathrm{~mm}$ in diameter after incubation at $30{ }^{\circ} \mathrm{C}$ for 3 days. Growth occurs at 20 $40{ }^{\circ} \mathrm{C}$ (optimum $30-35{ }^{\circ} \mathrm{C}$ ) and $\mathrm{pH}$ 6.0-10.0 (optimum $\mathrm{pH} 7.0-7.5) . \mathrm{NaCl}$ is not required for growth and the type strain can tolerate up to $2.0 \% \mathrm{NaCl}$ (optimum $0.5 \% \mathrm{NaCl}$ ). Negative for $\beta$-galactosidase, urease and production of indole and $\mathrm{H}_{2} \mathrm{~S}$. Hydrolyses Tweens 20 and 80 weakly, but starch, L-tyrosine, casein, arginine, gelatin and aesculin are not hydrolysed. Weak growth on L-arabinose, cellobiose, glucose, lactose, maltose, raffinose, sucrose, D-xylose, erythritol, glycerol and D-glucitol; no growth on sodium acetate, casein, citrate, citric acid, inositol, malic acid, methanol, L-rhamnose, sorbitol and succinic acid. With API ZYM, positive for alkaline phosphatase, esterase (C4), esterase lipase (C8), leucine arylamidase, phosphatase acid and naphthol-AS-BI-phosphohydrolase and weakly positive for lipase (C14), valine arylamidase and cystine arylamidase.
In addition to the major fatty acids listed for the genus, contains the minor fatty acids 11 -methyl $\mathrm{C}_{18: 1} \omega 7 c, \mathrm{C}_{18: 1} 2$ $\mathrm{OH}, \mathrm{C}_{16: 0} 3-\mathrm{OH}, \mathrm{C}_{14: 0}$, summed feature $3\left(\mathrm{C}_{16: 1} \omega 7 c\right.$ and/or iso- $\left.\mathrm{C}_{15: 0} 2-\mathrm{OH}\right)$ and $\mathrm{C}_{14: 0} 2-\mathrm{OH}$. Sensitive to ( $\mu$ g per disc unless otherwise stated) vancomycin (30), gentamicin (10), carbenicillin (100), polymyxin B (300 U), streptomycin (10), kanamycin (30), ampicillin (10), neomycin (30), chloramphenicol (30) and penicillin (10 U) and weakly sensitive to tetracycline (30), erythromycin (15), novobiocin (5) and rifampicin (5). The DNA G $+\mathrm{C}$ content of the type strain is $65.6 \mathrm{~mol} \%$.

The type strain is $\mathrm{LM} 22^{\mathrm{T}}$ (=CGMCC $1.7660^{\mathrm{T}}=\mathrm{JCM}$ $15798^{\mathrm{T}}$ ), isolated from a sequencing batch reactor for treatment of malachite green effluent.

\section{Acknowledgements}

This work was supported by grants from the High-Tech Development Program of China (863 Project; grant no. 2006AA06Z316), the Knowledge Innovation Program of the Chinese Academy of Sciences (grant no. KSCS2-YW-G-055-01) and the Beijing Academy of Science Technology (grant no. IE012009610019-1).

\section{References}

Alderman, D. J. (1985). Malachite green: a review. J Fish Dis 8, 289-298. Altschul, S. F., Gish, W., Miller, W., Myers, E. W. \& Lipman, D. J. (1990). Basic local alignment search tool. J Mol Biol 215, 403-410.

Bruns, A., Rohde, M. \& Berthe-Corti, L. (2001). Muricauda ruestringensis gen. nov., sp. nov., a facultatively anaerobic, appendaged bacterium from German North Sea intertidal sediment. Int $J$ Syst Evol Microbiol 51, 1997-2006.

Choi, D. H., Hwang, C. Y. \& Cho, B. C. (2009). Pelagibius litoralis gen. nov., sp. nov., a marine bacterium in the family Rhodospirillaceae isolated from coastal seawater. Int J Syst Evol Microbiol 59, 818-823.

Coenye, T., Goris, J., Spilker, T., Vandamme, P. \& LiPuma, J. J. (2002). Characterization of unusual bacteria isolated from respiratory secretions of cystic fibrosis patients and description of Inquilinus limosus gen. nov., sp. nov. J Clin Microbiol 40, 2062-2069.

Cowan, S. T. \& Steel, K. J. (1965). Manual for the Identification of Medical Bacteria. London: Cambridge University Press.

Dong, X.-Z. \& Cai, M.-Y. (2001). Determinative Manual for Routine Bacteriology. Beijing: Science Press (in Chinese). 
Dong, C., Lai, Q., Chen, L., Sun, F., Shao, Z. \& Yu, Z. (2010). Oceanibaculum pacificum sp. nov., isolated from hydrothermal field sediment of the Southwest Pacific Ocean. Int J Syst Evol Microbiol 60, 219-222.

Eckert, B., Weber, O. B., Kirchhof, G., Halbritter, A., Stoffels, M. \& Hartmann, A. (2001). Azospirillum doebereinerae sp. nov., a nitrogenfixing bacterium associated with the $\mathrm{C}_{4}$-grass Miscanthus. Int J Syst Evol Microbiol 51, 17-26.

Favinger, J., Stadtwald, R. \& Howard, G. (1989). Rhodospirillum centenum sp. nov., a thermotolerant cyst-forming anoxygenic photosynthetic bacterium. Antonie van Leeuwenhoek 55, 291-296.

Gerhardt, P., Murray, R. G. E., Wood, W. A. \& Krieg, N. R. (editors) (1994). Methods for General and Molecular Bacteriology. Washington, DC: American Society for Microbiology.

Imhoff, J. F. \& Caumette, P. (2004). Recommended standards for the description of new species of anoxygenic phototrophic bacteria. Int $J$ Syst Evol Microbiol 54, 1415-1421.

Imhoff, J. F., Petri, R. \& Suling, J. (1998). Reclassification of species of the spiral-shaped phototrophic purple non-sulfur bacteria of the $\alpha$ Proteobacteria: description of the new genera Phaeospirillum gen. nov., Rhodovibrio gen. nov., Rhodothalassium gen. nov. and Roseospira gen. nov. as well as transfer of Rhodospirillum fulvum to Phaeospirillum fulvum comb. nov., of Rhodospirillum molischianum to Phaeospirillum molischianum comb. nov., of Rhodospirillum salinarum to Rhodovibrio salinarum comb. nov., of Rhodospirillum sodomense to Rhodovibrio sodomensis comb. nov., of Rhodospirillum salexigens to Rhodothalassium salexigens comb. nov. and of Rhodospirillum mediosalinum to Roseospira mediosalina comb. nov. Int J Syst Bacteriol 48, 793-798.

Kawasaki, H., Hoshino, Y., Kuraiski, Y. \& Yamasato, K. (1992). Rhodocista centenaria gen. nov., sp. nov., a cyst-forming anoxygenic photosynthetic bacterium and its phylogenetic position in the Proteobacteria alpha group. J Gen Appl Microbiol 38, 541-551.

Khammas, K. M., Ageron, E., Grimont, P. A. D. \& Kaiser, P. (1989). Azospirillum irakense sp. nov., a nitrogen-fixing bacterium associated with rice roots and rhizosphere soil. Res Microbiol 140, 679-693.

Komagata, K. \& Suzuki, K. (1987). Lipid and cell-wall analysis in bacterial systematics. Methods Microbiol 19, 161-207.

Kumar, S., Tamura, K. \& Nei, M. (2004). MEGA3: integrated software for molecular evolutionary genetics analysis and sequence alignment. Brief Bioinform 5, 150-163.

Labrenz, M., Tindall, B. J., Lawson, P. A., Collins, M. D., Schumann, P. \& Hirsch, P. (2000). Staleya guttiformis gen. nov., sp. nov. and Sulfitobacter brevis sp. nov., $\alpha$-3-Proteobacteria from hypersaline, heliothermal and meromictic antarctic Ekho Lake. Int J Syst Evol Microbiol 50, 303-313.

Lai, Q., Yuan, J., Gu, L. \& Shao, Z. (2009a). Marispirillum indicum gen. nov., sp. nov., isolated from a deep-sea environment. Int J Syst Evol Microbiol 59, 1278-1281.

Lai, Q., Yuan, J., Wu, C. \& Shao, Z. (2009b). Oceanibaculum indicum gen. nov., sp. nov., isolated from deep seawater of the Indian Ocean. Int J Syst Evol Microbiol 59, 1733-1737.

Lane, D. J. (1991). 16S/23S rRNA sequencing. In Nucleic Acid Techniques in Bacterial Systematics, pp. 115-175. Edited by E. Stackebrandt \& M. Goodfellow. Chichester: Wiley.

Lin, S.-Y., Young, C. C., Hupfer, H., Siering, C., Arun, A. B., Chen, W.-M., Lai, W.-A., Shen, F.-T., Rekha, P. D. \& Yassin, A. F. (2009). Azospirillum picis sp. nov., isolated from discarded tar. Int J Syst Evol Microbiol 59, 761-765.

López-López, A., Pujalte, M. J., Benlloch, S., Mata-Roig, M., Rosselló-Mora, R., Garay, E. \& Rodríguez-Valera, F. (2002).
Thalassospira lucentensis gen. nov., sp. nov., a new marine member of the $\alpha$-Proteobacteria. Int J Syst Evol Microbiol 52, 1277-1283.

Mehnaz, S., Weselowski, B. \& Lazarovits, G. (2007a). Azospirillum canadense sp. nov., a nitrogen-fixing bacterium isolated from corn rhizosphere. Int J Syst Evol Microbiol 57, 620-624.

Mehnaz, S., Weselowski, B. \& Lazarovits, G. (2007b). Azospirillum zeae sp. nov., a diazotrophic bacterium isolated from rhizosphere soil of Zea mays. Int J Syst Evol Microbiol 57, 2805-2809.

Peng, G., Wang, H., Zhang, G., Hou, W., Liu, Y., Wang, E. T. \& Tan, Z. (2006). Azospirillum melinis sp. nov., a group of diazotrophs isolated from tropical molasses grass. Int J Syst Evol Microbiol 56, 1263-1271.

Pfennig, N. \& Trüper, H. G. (1974). The phototrophic bacteria. In Bergey's Manual of Determinative Bacteriology, 8th edn, pp. 24-75. Edited by R. E. Buchanan \& N. E. Gibbons. Baltimore: Williams \& Wilkins.

Reinhold, B., Hurek, T., Fendrik, I., Pot, B., Gillis, M., Kersters, K., Thielemans, S. \& De Ley, J. (1987). Azospirillum halopraeferens sp. nov., a nitrogen-fixing organism associated with roots of kallar grass (Leptochloa fusca (L.) Kunth). Int J Syst Bacteriol 37, 43-51.

Schenk, S. U. \& Werner, D. (1988). Fatty acid analysis of four Azospirillum species reveals three groups. Arch Microbiol 149, 580582.

Sizova, M. V., Panikov, N. S., Spiridonova, E. M., Slobodova, N. V. \& Tourova, T. P. (2007). Novel facultative anaerobic acidotolerant Telmatospirillum siberiense gen. nov. sp. nov. isolated from mesotrophic fen. Syst Appl Microbiol 30, 213-220.

Sly, L. I. \& Stackebrandt, E. (1999). Description of Skermanella parooensis gen. nov., sp. nov. to accommodate Conglomeromonas largomobilis subsp. parooensis following the transfer of Conglomeromonas largomobilis subsp. largomobilis to the genus Azospirillum. Int J Syst Bacteriol 49, 541-544.

Sly, L. I., Blackall, L. L., Kraat, P. C., Tian-Shen, T. \& Sangkhobol, V. (1986). The use of second derivative plots for the determination of mol\% guanine plus cytosine of DNA by the thermal denaturation method. J Microbiol Methods 5, 139-156.

Srivastava, S., Sinha, R. \& Roy, D. (2004). Toxicological effects of malachite green. Aquat Toxicol 66, 319-329.

Stanier, R. Y., Palleroni, N. J. \& Doudoroff, M. (1966). The aerobic pseudomonads: a taxonomic study. J Gen Microbiol 43, 159-271.

Tarrand, J. J., Krieg, N. R. \& Döbereiner, J. (1978). A taxonomic study of the Spirillum lipoferum group, with description of a new genus, Azospirillum gen. nov., and two species, Azospirillum lipoferum (Beijerinck) comb. nov., and Azospirillum brasilense sp. nov. Can J Microbiol 24, 967-980.

Thompson, J. D., Gibson, T. J., Plewniak, F., Jeanmougin, F. \& Higgins, D. G. (1997). The CLUSTAL_X windows interface: flexible strategies for multiple sequence alignment aided by quality analysis tools. Nucleic Acids Res 25, 4876-4882.

Urios, L., Michotey, V., Intertaglia, L., Lesongeur, F. \& Lebaron, P. (2008). Nisaea denitrificans gen. nov., sp. nov. and Nisaea nitritireducens sp. nov., two novel members of the class Alphaproteobacteria from the Mediterranean Sea. Int J Syst Evol Microbiol 58, 2336-2341.

Urios, L., Michotey, V., Intertaglia, L., Lesongeur, F. \& Lebaron, P. (2010). Thalassobaculum salexigens sp. nov., a new member of the family Rhodospirillaceae from the NW Mediterranean Sea, and emended description of the genus Thalassobaculum. Int J Syst Evol Microbiol 60, 209-213.

Wang, Y.-X., Liu, J.-H., Zhang, X.-X., Chen, Y.-G., Wang, Z.-G., Chen, Y., Li, Q.-Y., Peng, Q. \& Cui, X.-L. (2009). Fodinicurvata sediminis gen. nov., sp. nov. and Fodinicurvata fenggangensis sp. nov., poly- $\beta$-hydroxybu- 
tyrate-producing bacteria in the family Rhodospirillaceae. Int J Syst Evol Microbiol 59, 2575-2581.

Xie, C.-H. \& Yokota, A. (2005). Azospirillum oryzae sp. nov., a nitrogen-fixing bacterium isolated from the roots of the rice plant Oryza sativa. Int J Syst Evol Microbiol 55, 1435-1438.

Yoon, J.-H., Kang, S.-J., Park, S. \& Oh, T.-K. (2007). Caenispirillum bisanense gen. nov., sp. nov., isolated from sludge of a dye works. Int $J$ Syst Evol Microbiol 57, 1217-1221.

Young, C. C., Hupfer, H., Siering, C., Ho, M.-J., Arun, A. B., Lai, W.-A., Rekha, P. D., Shen, F.-T., Hung, M.-H. \& other authors (2008).
Azospirillum rugosum sp. nov., isolated from oil-contaminated soil. Int J Syst Evol Microbiol 58, 959-963.

Zhang, D., Yang, H., Zhang, W., Huang, Z. \& Liu, S.-J. (2003). Rhodocista pekingensis sp. nov., a cyst-forming phototrophic bacterium from a municipal wastewater treatment plant. Int J Syst Evol Microbiol 53, 1111-1114.

Zhang, G. I., Hwang, C. Y. \& Cho, B. C. (2008). Thalassobaculum litoreum gen. nov., sp. nov., a member of the family Rhodospirillaceae isolated from coastal seawater. Int J Syst Evol Microbiol 58, 479485 . 